\title{
Application of a byproduct of guava processing in an Ultisol, in the presence and absence of mineral fertilization
}

\author{
Aplicación de un subproducto del procesamiento de guayaba en un Ultisol, \\ en presencia y en ausencia de fertilización mineral \\ Danilo Eduardo Rozane ${ }^{1 *}$, Mariana Hortense Torres ${ }^{2}$, Henrique Antunes de Souza ${ }^{3}$, \\ William Natale ${ }^{4}$, Silvia Helena Modenese Gorla da Silva ${ }^{5}$
}

\begin{abstract}
There is a relative lack of technical studies on the adequate management of organic wastes from food processing. The aim of this study was to evaluate the effect of applying doses of a byproduct from guava processing, in the presence and absence of mineral fertilization, on the fertility of a an Ultisol (or Red-Yellow Argisol) under laboratory conditions. An entirely randomized 5x2 factorial experimental design was used with five byproduct doses, in the presence and absence of mineral fertilization, with four repetitions, for a total of 40 experimental units. Under the experimental conditions, the attributes $\mathrm{pH}, \mathrm{OM}, \mathrm{K}, \mathrm{Mg}, \mathrm{BS}, \mathrm{T}, \mathrm{V}, \mathrm{B}, \mathrm{Fe}, \mathrm{Zn}$ and $\mathrm{S}_{-} \mathrm{SO}_{4}{ }^{2-}$ were affected by the guava byproduct doses, as well as by the presence or absence of mineral fertilization. With the use of this fertilization, the variables $\mathrm{OM}, \mathrm{K}, \mathrm{H}+\mathrm{Al}, \mathrm{T}, \mathrm{Fe}$ and $\mathrm{Zn}$ increased more as a function of byproduct dose than in the absence of fertilization. The results obtained demonstrate the potential of using this waste material in the cycling and supply of nutrients.

Key words: Psidium guajava, guava residue, organic fertilization, guava, orchard.
\end{abstract}

\section{RESUMEN}

Hay una relativa falta de estudios técnicos sobre el manejo adecuado de los residuos orgánicos de elaboración de alimentos. El objetivo de este estudio fue evaluar el efecto de la aplicación de dosis de un subproducto del procesamiento de guayaba, en presencia y en ausencia de fertilización mineral, sobre la fertilidad de un Ultisol en condiciones de laboratorio. El diseño de experimento utilizado en este estudio fue un factorial de $5 \times 2$, con cinco dosis de subproductos, en presencia y en ausencia de fertilización mineral, con cuatro repeticiones, para un total de 40 unidades experimentales. En las condiciones experimentales, los atributos de $\mathrm{pH}, \mathrm{MO}, \mathrm{K}, \mathrm{Mg}, \mathrm{SB}, \mathrm{T}, \mathrm{V}, \mathrm{B}, \mathrm{Fe}, \mathrm{Zn}$ y $\mathrm{S}_{-} \mathrm{SO}_{4}{ }^{2-}$ se vieron afectados por las dosis de subproducto de guayaba, así como por la presencia o ausencia de fertilización mineral. Con el uso de fertilización mineral, las variables $M O, K, H+A l, T, F e$ y Zn aumentaron más que en función de la dosis subproducto en ausencia de fertilización. Los resultados obtenidos demuestran el potencial del uso de este material en el ciclo y el suministro de nutrientes.

Palabras clave: Psidium guajava, residuo de guayaba, fertilización orgánica, guayaba, cultivo.

\section{Introduction}

With the increasing cost of mineral fertilizers, organic wastes have been attracting greater attention from researchers and farmers, with priority given to the resources available in each region.
In Brazil, the state of São Paulo is the leading guava producer, with $31 \%$ of national output, producing some 98 thousand tonnes of fruit a year, of which $70 \%$ is processed, mainly to make juice as well as jam and other sweets (Agrianual, 2013). The region composed of the municipalities of Vista

1 Departamento de Agronomia, Universidade Estadual Paulista "Julio de Mesquita Filho" (Unesp), Campus de Registro, Rua: Nelson Brihi Badur, 430, Vila Tupy-11900-000, Registro, SP, Brazil.

2 Departamento de Solos e Adubos, Universidade Estadual Paulista "Julio de Mesquita Filho" (Unesp), Campus de Jaboticabal, Via de Acesso Prof. Paulo Donato Castellane, s/n - km 04 - 14884-900, Jaboticabal, SP, Brazil.

3 Embrapa Caprinos e Ovinos, Estrada Sobral/Groaíras, km 04 - Caixa Postal 145 - 62010-970, Sobral, CE, Brazil.

4 Departamento de Solos e Adubos, Universidade Estadual Paulista "Julio de Mesquita Filho" (Unesp), Campus de Jaboticabal, Via de Acesso Prof. Paulo Donato Castellane, s/n - km 04 - 14884-900, Jaboticabal, SP, Brazil.

5 Departamento de Agronomia, Universidade Estadual Paulista "Julio de Mesquita Filho" (Unesp), Campus de Registro, Rua: Nelson Brihi Badur, 430, Vila Tupy-11900-000, Registro, SP, Brazil.

* Corresponding author: danilorozane@ registro.unesp.br 
Alegre do Alto, Monte Alto and Taquaritinga is the state's main grower of the fruit (Lupa, 2008). As a consequence there are several guava processing industries in this region.

The main residue produced is the material left over after mechanical pulping, representing about $8 \%$ by weight of the fruits processed. This means that Brazil produces about 5 thousand tonnes of guava byproduct annually, which could be used in agriculture because it basically consists of ground seeds, making it a "clean byproduct" that is rich in nutrients.

Some works in the literature have reported the potential of using guava processing residue. Corrêa et al. (2005) reported that the use of this material promoted an increase in organic matter and potassium in the soil, besides decreases of $\mathrm{pH}$. Mantovani et al. (2004), evaluating the application of this byproduct on corn in greenhouse experiments, concluded that the residue is a source of slow release of $\mathrm{N}$ and $\mathrm{P}$ to the plants.

The use of organic wastes, especially from food processing, is a practice that aims to recycle nutrients, improve soil fertility and take economic advantage of these byproducts in the regions where they are produced, so as to reduce cost of buying mineral fertilizers and the environmental impacts of the improper disposal of this material.

In light of this scenario and given the scarcity of information in the literature on the subject, the aim of this study was to assess the effect of applying doses of this byproduct of the guava processing industry, in the presence and absence of mineral fertilization, on the fertility of an Ultisol (Red-Yellow Argisol) under laboratory conditions.

\section{Material and Methods}

The study was carried out under laboratory conditions in the Department of Soils and Fertilizers of the School of Agrarian and Veterinary Sciences of Unesp, Jaboticabal Campus, in São Paulo, Brazil.

The soil used in the experiment came from an orchard of adult guava trees (five years of age) of the Paluma cultivar, located in the leading guava producing region of São Paulo, the municipality of Vista Alegre do Alto, with geographic coordinates $21^{\circ} 08^{\prime} \mathrm{S}, 48^{\circ} 30^{\prime} \mathrm{W}$ and altitude of $603 \mathrm{~m}$.

The soil in the orchard was classified as dystrophic Ultisol, or Red-Yellow Argisol, with medium sandy texture, according to Embrapa
(2006). The soil sample was collected under the projection of the tree crowns, at a depth of $0-20$ $\mathrm{cm}$, and was analyzed before use in the treatments according to the method described by Raij et al. (2001). The results were: $\mathrm{pH}\left(\mathrm{CaCl}_{2}\right)=5.4$; $\mathrm{OM}=17 \mathrm{~g} \mathrm{dm}^{-3} ; \mathrm{P}=48 \mathrm{mg} \mathrm{dm}^{-3} ; \mathrm{K}^{+}=3.1 \mathrm{mmol}_{\mathrm{c}}$ $\mathrm{dm}^{-3} ; \mathrm{Ca}^{+2}=28 \mathrm{mmol}_{\mathrm{c}} \mathrm{dm}^{-3} ; \mathrm{Mg}^{+2}=15 \mathrm{mmol}_{\mathrm{c}}$ $\mathrm{dm}^{-3} ;(\mathrm{H}+\mathrm{Al})=21 \mathrm{mmol}_{\mathrm{c}} \mathrm{dm}^{-3} ;$ Base Saturation $(\mathrm{BS})=46.1 \mathrm{mmol}_{\mathrm{c}} \mathrm{dm}^{-3} ; \mathrm{T}=67.1 \mathrm{mmol}_{\mathrm{c}} \mathrm{dm}^{-3}$; $\mathrm{V}=69 \% ; \mathrm{B}=0.21 \mathrm{mg} \mathrm{dm}^{-3} ; \mathrm{Cu}=14.3 \mathrm{mg} \mathrm{dm}^{-3}$; $\mathrm{Fe}=18.7 \mathrm{mg} \mathrm{dm}^{-3} ; \mathrm{Mn}=26.1 \mathrm{mg} \mathrm{dm}^{-3} ; \mathrm{Zn}=0.9 \mathrm{mg}$ $\mathrm{dm}^{-3}$; and $\mathrm{S}_{-} \mathrm{SO}_{4}^{-2}=6 \mathrm{mg} \mathrm{dm}^{-3}$.

According to the recommendations of Natale et al. (1996) and Natale et al. (2007), the base saturation and fertility conditions of this soil studied are adequate for producing satisfactory guava yields, without the need for correction of acidity.

The industrial by product employed in this study consisted basically of ground seeds together with a small fraction of the skin and pulp not separated during the pulping process, carried out after washing the fruits. The chemical contents were estimated according to the method described by Bataglia et al. (1983), which showed the following results: 4.7, 11.6, 1,749, 18.7, 290, 2.1, 2.3, 0.8, 0.9, 1.3, 10, $10,150,12,28$ and 25 , respectively, for $\mathrm{pH}, \mathrm{N}_{\text {total }}$ $\left(\mathrm{g} \mathrm{kg}^{-1}\right), \mathrm{N}^{-\mathrm{NH}_{4}}{ }^{+}, \mathrm{N}^{-\mathrm{NO}_{3}}{ }^{-}\left(\mathrm{mg} \mathrm{kg}^{-1}\right), \mathrm{C}_{\text {organic }}, \mathrm{P}, \mathrm{K}$, $\mathrm{Ca}, \mathrm{Mg}, \mathrm{S}\left(\mathrm{g} \mathrm{kg}^{-1}\right), \mathrm{B}, \mathrm{Cu}, \mathrm{Fe}, \mathrm{Mn}, \mathrm{Zn}\left(\mathrm{mg} \mathrm{kg}^{-1}\right)$ and $\mathrm{C} / \mathrm{N}$. The byproduct was applied once each year from 2006 to 2010 at the beginning of the year.

The calculation of the byproduct doses to be applied in each treatment was done based on the volume of soil used, considering the incorporation of the material in the layer from 0 to $20 \mathrm{~cm}$. In each treatment the byproduct was homogenized with the soil and the moisture was kept at $70 \%$ of field capacity, controlled by weighing the pots and applying deionized water as needed.

A fully randomized $5 \times 2$ factorial design was used, with four repetitions, for a total of 40 experimental units. Each unit was composed of a polyethylene pot with capacity of $150 \mathrm{~mL}$, in which the soil samples received the various treatments, consisting of five guava byproduct doses, with and without the application of mineral fertilization.

The mineral fertilization followed the recommendation of Natale et al. (1996), based on the analysis of the soil collected in the area, corresponding to expected fruit yield of $100 \mathrm{tha}^{-1}$. Therefore, the quantity of mineral fertilizer applied in each experimental unit corresponded to $34.45 \mathrm{mg}$ 
of urea, $15.88 \mathrm{mg}$ of simple superphosphate and $9.57 \mathrm{mg}$ of potassium chloride. The quantities of the byproduct applied (dry matter) in each $150-\mathrm{mL}$ pot were zero, 0.603, 1.206, 1.809 and $2.412 \mathrm{~g}$, or doses equivalent to zero, 9, 18, 27 and $36 \mathrm{tha}^{-1}$ respectively.

At the end of 180 days, the soil in each pot was air dried, passed through a 2-mm mesh sieve and analyzed according to the method described by Raij et al. (2001).

We performed analysis of variance (F-test) on the data obtained, and when significant, we applied polynomial regression, with the aid of the AgroEstat program (Barbosa and Maldonado Júnior, 2009).

\section{Results and Discussion}

After six months of incubation of the soil samples with the guava processing byproduct, a significant effect was observed of the interaction (byproduct dose vs. mineral fertilization) on the parameters evaluated, both in the routine analysis and that of micronutrients and sulfur (Tables 1 and 2).

For $\mathrm{pH}, \mathrm{OM}, \mathrm{K}, \mathrm{Mg}, \mathrm{BS}, \mathrm{H}+\mathrm{Al}, \mathrm{T}$ and $\mathrm{V}$, there were significant differences in relation to the byproduct doses applied and also for the presence or absence of mineral fertilization. No significant effect was noted for phosphorus, and for calcium there was only a significant effect regarding use or not of mineral fertilization (Table 1).
Among the micronutrients, $\mathrm{B}, \mathrm{Cu}, \mathrm{Mn}$ and $\mathrm{Zn}$, as well as $\mathrm{S}_{-} \mathrm{SO}_{4}{ }^{2}$, showed significant differences in function of the byproduct doses, while for B, $\mathrm{Fe}, \mathrm{Zn}$ and $\mathrm{S}_{-} \mathrm{SO}_{4}{ }^{-2}$ there was a positive effect of application of mineral fertilization in relation to the absence of fertilization (Table 2).

The regression analysis revealed that the $\mathrm{pH}$ value declined linearly in proportion to the byproduct doses, both in the absence and presence of mineral fertilization. The reduction in the $\mathrm{pH}$ value in its presence was 1.6 for each 9 tonnes per hectare of byproduct used and was 1.2 in its absence. In other words, the use of the mineral fertilizer increased the acidification effect of the byproduct (Figure 1a).

During the decomposition of organic matter, ammonium $\left(\mathrm{NH}_{4}^{+}\right)$is formed, and in the transformation of $\mathrm{N}-\mathrm{NH}^{+}{ }^{+}$to ${\mathrm{N}-\mathrm{NO}^{-}}^{-}$(nitrate), $\mathrm{H}^{+}$ions are released, resulting in acidification of the soil, with consequent reduction of the $\mathrm{pH}$. In the present study, the source of $\mathrm{N}$ used was urea $\left[\mathrm{CO}\left(\mathrm{NH}_{2}\right)_{2}\right]$, which after by breaking Urease and other transformations, results in the release of $\mathrm{H}^{+}$ions (Malavolta, 2006). Therefore, both the decomposition of the byproduct and the application of the mineral fertilizer explain the soil acidification.

Mantovani et al. (2004) and Corrêa et al. (2005) observed similar results (reduction of $\mathrm{pH}$ ) in experiments with waste material from guava processing, corroborating the results observed in this study.

Table 1. Summary of the analysis of variance of the chemical attributes from routine analysis of an Ulitsol, collected in an orchard containing adult guava trees (Paluma cultivar) as a function of applying guava processing byproduct in the presence and absence of mineral fertilization, after six months of incubation (mean of four repetitions).

\begin{tabular}{|c|c|c|c|c|c|c|c|c|c|c|}
\hline $\begin{array}{c}\text { Variation } \\
\text { Doses (D) }\end{array}$ & $\begin{array}{c}\mathrm{pH} \\
\left(\mathrm{CaCl}_{2}\right)\end{array}$ & $\mathrm{OM}$ & $\mathrm{P}($ resin $)$ & $\mathrm{K}$ & $\mathrm{Ca}$ & $\mathrm{Mg}$ & $(\mathrm{H}+\mathrm{Al})$ & BS & $\mathrm{T}$ & V \\
\hline $\mathrm{tha}^{-1}$ & & $\mathrm{~g} \mathrm{dm}^{-3}$ & $\mathrm{mg} \mathrm{dm}{ }^{-3}$ & \multicolumn{6}{|c|}{$\mathrm{mmol}_{\mathrm{c}} \mathrm{dm}^{-3}$} & $\%$ \\
\hline 0 & 5.4 & 18 & 47 & 3.3 & 28 & 16 & 19 & 47 & 66 & 72 \\
\hline 9 & 5.3 & 20 & 42 & 3.4 & 28 & 16 & 20 & 47 & 66 & 71 \\
\hline 18 & 5.2 & 23 & 40 & 3.7 & 28 & 17 & 21 & 48 & 69 & 70 \\
\hline 27 & 5.0 & 25 & 47 & 3.9 & 29 & 17 & 23 & 49 & 72 & 68 \\
\hline 36 & 4.9 & 29 & 50 & 4.2 & 30 & 19 & 26 & 52 & 78 & 67 \\
\hline F-test & $80.56^{* *}$ & $36.35^{* *}$ & $2.26^{\mathrm{ns}}$ & $27.56^{* *}$ & $2.14^{\mathrm{ns}}$ & $9.53^{* *}$ & $31.30^{* *}$ & $7.87^{* *}$ & $25.41^{* *}$ & $12.3^{* *}$ \\
\hline Fertilization $(\mathrm{F})$ & & & & & & & & & & \\
\hline Absence & 5.4 & 22 & 46 & 3.1 & 26 & 15 & 18 & 44 & 63 & 71 \\
\hline Presence & 4.9 & 24 & 45 & 4.3 & 30 & 18 & 25 & 53 & 77 & 68 \\
\hline F-test & $766.09^{* *}$ & $11.07^{* *}$ & $0.05^{\mathrm{ns}}$ & $286.80 * *$ & $72.04 * *$ & $78.52^{* *}$ & $202.80^{* *}$ & $128.60^{* *}$ & $268.72^{* *}$ & $32.22^{* *}$ \\
\hline D x F Interaction & $1.06^{\mathrm{ns}}$ & $0.73^{\mathrm{ns}}$ & $2.00^{\mathrm{ns}}$ & $1.50^{\mathrm{ns}}$ & $2.94^{\mathrm{ns}}$ & $1.99^{\mathrm{ns}}$ & $1.71^{\mathrm{ns}}$ & $2.81^{\mathrm{ns}}$ & $2.80^{\mathrm{ns}}$ & $1.73^{\mathrm{ns}}$ \\
\hline $\mathrm{CV}(\%)$ & 9.2 & 18.8 & 26.5 & 15.7 & 15.4 & 16.3 & 16.7 & 14.7 & 14.0 & 12.2 \\
\hline
\end{tabular}

$*$ and $* *-p<0.05$ and $\mathrm{p}<0.01$ respectively. 
Table 2. Summary of the analysis of variance of chemical analysis of micronutrients plus sulfur in an Ultisol, collected in an orchard containing adult guava trees (Paluma cultivar) as a function of applying guava processing byproduct in the presence and absence of mineral fertilization, after six months of incubation (mean of four repetitions).

\begin{tabular}{|c|c|c|c|c|c|c|}
\hline $\begin{array}{c}\text { Variation } \\
\text { Doses (D) }\end{array}$ & B & $\mathrm{Cu}$ & $\mathrm{Fe}$ & $\mathrm{Mn}$ & $\mathrm{Zn}$ & $\mathrm{S}-\mathrm{SO}_{4}^{-2}$ \\
\hline $\mathrm{tha}^{-1}$ & & & $\mathrm{mg} \mathrm{dm}{ }^{-3}$ & & & $\mathrm{~g} \mathrm{dm}^{-3}$ \\
\hline 0 & 0.19 & 14.1 & 18 & 25,9 & 1,1 & 6 \\
\hline 9 & 0.19 & 12.8 & 18 & 24,7 & 1,1 & 7 \\
\hline 18 & 0.19 & 12.7 & 19 & 24,0 & 1,1 & 6 \\
\hline 27 & 0.22 & 12.1 & 20 & 24,6 & 1,3 & 7 \\
\hline 36 & 0.24 & 11.8 & 21 & 25,1 & 1,3 & 10 \\
\hline F-test & $10.48^{* *}$ & $7.79^{* *}$ & $50,05^{* *}$ & $2,07^{\mathrm{ns}}$ & $20,23^{* *}$ & $5,73^{* *}$ \\
\hline \multicolumn{7}{|l|}{ Fertilization $(\mathrm{F})$} \\
\hline Absence & 0.17 & 12.7 & 16,6 & 25,2 & 1,1 & 4,0 \\
\hline Presence & 0.23 & 12.9 & 21,3 & 24,5 & 1,3 & 11,0 \\
\hline F-test & $90.00^{* *}$ & $0.33^{\mathrm{ns}}$ & $697.58^{* *}$ & $3.17^{\mathrm{ns}}$ & $63.71^{* *}$ & $140.67^{* *}$ \\
\hline D x F Interaction & $2.27^{\mathrm{ns}}$ & $5.13^{\mathrm{ns}}$ & $4.82^{\mathrm{ns}}$ & $3.91^{\mathrm{ns}}$ & $1.83^{\mathrm{ns}}$ & $0.97^{\mathrm{ns}}$ \\
\hline $\mathrm{CV}(\%)$ & 19.8 & 16.0 & 23.0 & 35.5 & 16.5 & 26.5 \\
\hline
\end{tabular}

$*$ and $* *-\mathrm{p}<0.05$ and $\mathrm{p}<0.01$ respectively.

The concentration of organic matter in response to application of the byproduct doses fit a rising linear model (Figure 1b), independently of the presence or absence of mineral fertilization. This increase in organic matter can be explained by the high organic carbon content of the waste material employed. Corrêa et al. (2005) pointed out that the increase of organic matter in the soil in function of application of this byproduct is possibly due to the contribution of both the humified and nonhumified organic matter. In the presence of mineral fertilization, the increase in organic matter for each $9 \mathrm{tha}^{-1}$ of byproduct was $3.3 \mathrm{~g} \mathrm{dm}^{-3}$, while without mineral fertilization it was $2.6 \mathrm{~g} \mathrm{dm}^{-3}$ (Figure 1b).

Reports in the literature of experiments with other organic materials indicate increases in the concentration of organic matter after a certain time interval. Prado and Natale (2005) observed an increase in organic matter after the application of textile sludge in studying the development and nutritional state of passion fruit trees. According to Malavolta (1989), the addition of organic matter, whether from natural sources or through fertilization, promotes the gradual release of nutrients, favoring their utilization by plants, since the elements are made available slowly. Besides this, the increase of organic matter concentration in the soil is the main benefit of applying organic wastes, due to their contribution to improve the soil's chemical, physical and biological properties (Berton et al., 1989).
There was no significant effect of the treatments on the phosphorus concentration in the soil. Even the application of rising byproduct doses and mineral fertilization with simple superphosphate did not produce a significant change. Possible explanations can be associated with the high levels of P initially present in the soil used and/or that the increase in organic matter levels caused chelatization of the $\mathrm{P}$, and/or that with the increased byproduct doses and soil acidification, there was greater fixation of phosphate, as also noted by Novais and Smyth (1999).

With regard to potassium (Figure 1c), there was a significant linear increase in its concentration in the soil with rising byproduct doses, both in the absence and presence of mineral fertilizer. With fertilization, the increase in the $\mathrm{K}$ concentration was $0.28 \mathrm{mmol}_{\mathrm{c}}$ $\mathrm{dm}^{-3}$ and without it the increase was $0.23 \mathrm{mmol}_{\mathrm{c}}$ $\mathrm{dm}^{-3}$ for each $9 \mathrm{t} \mathrm{ha}^{-1}$ of the byproduct. Corrêa et al. (2005) reported linear increases in potassium in the soil after application of rising doses of the same type of byproduct, in an experiment that lasted 90 days. Mantovani et al. (2004) also observed higher potassium concentrations in the soil with the use of a waste material from guava processing in a greenhouse experiment with corn plants.

As can be seen in Table 1, the concentration of calcium was greater in the presence than in the absence of mineral fertilization. This can be explained by the use of simple superphosphate as fertilizer, because it contains a large quantity of $\mathrm{Ca}$ in its 
(a)

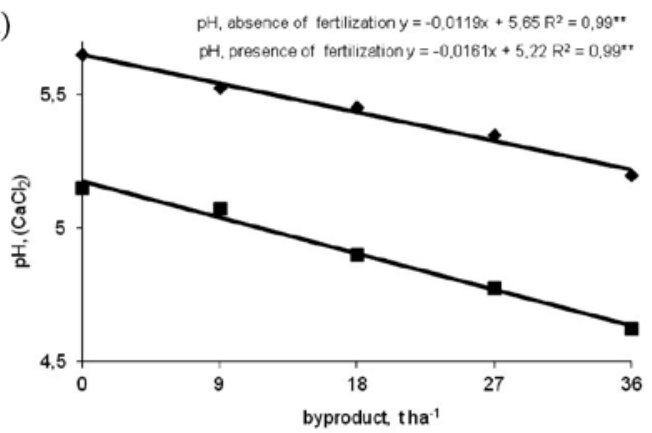

(c)

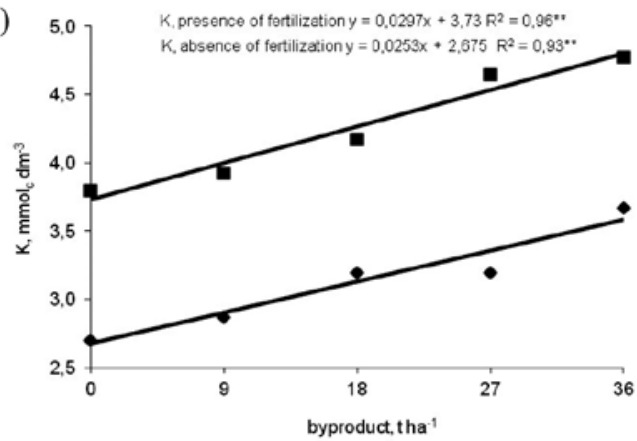

(e) $20 \quad$ Ma. presence of tertilization $y=18^{\mathrm{n}} \mathrm{s}$

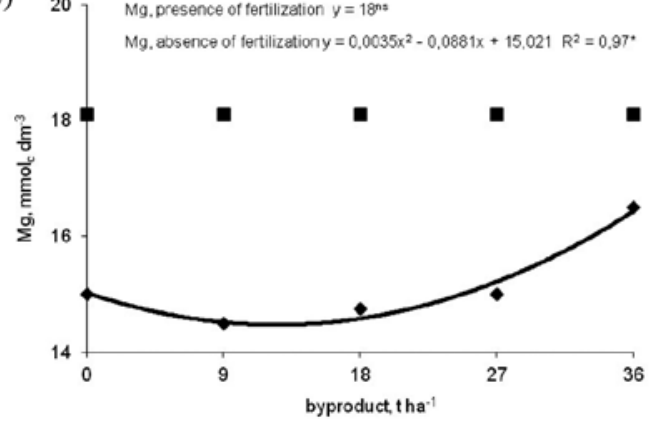

(b)

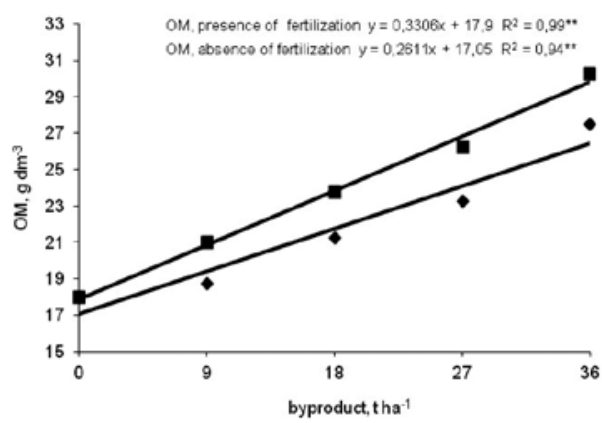

(d)

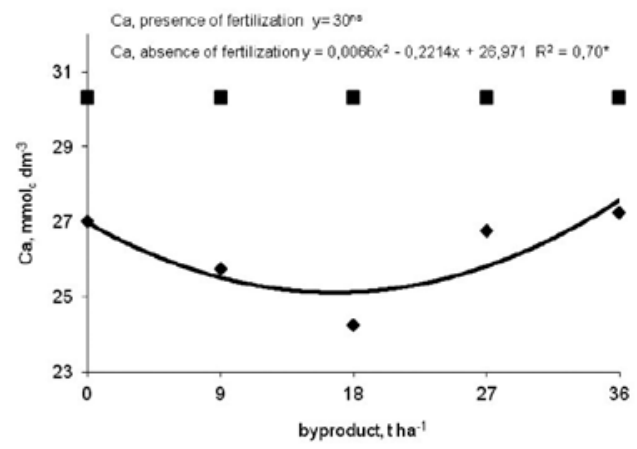

(f)

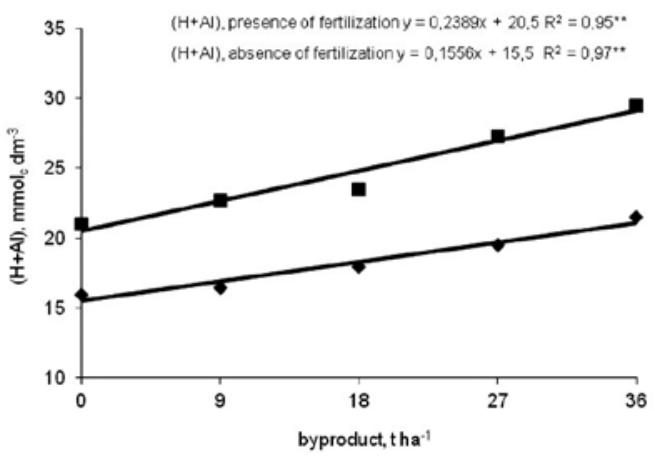

Figure 1. Effect of applying increasing doses of guava byproduct, in the absence () and presence () of mineral fertilization, on the parameters $\mathrm{pH}(\mathrm{a}) ; \mathrm{OM}(\mathrm{b}) ; \mathrm{K}(\mathrm{c}) ; \mathrm{Ca}(\mathrm{d}) ; \mathrm{Mg}$ (e) and $\mathrm{H}+\mathrm{Al}$ (f). * and ** $-\mathrm{p}<0.05$ and $\mathrm{p}<0.01$ respectively.

formula (Figure $1 \mathrm{~d}$ ). With respect to magnesium (Figure 1e), the soil concentrations increased with the byproduct dose level in the absence of mineral fertilization but the result was not significant when fertilizer was applied. In other words, with mineral fertilization there was no significant difference in magnesium levels between the various byproduct doses employed. Mantovani et al. (2004) and Corrêa et al. (2005) did not find changes in the concentrations of $\mathrm{Ca}$ and $\mathrm{Mg}$ in the soil in function of the application of guava processing waste, even when the doses reached $120 \mathrm{tha}^{-1}$.
There was a linear increase in the level of $\mathrm{H}+\mathrm{Al}$ with the application of rising byproduct doses, regardless of the presence or absence of mineral fertilization (Figure 1f). There is a known direct relation between $\mathrm{pH}$ and potential soil acidity, which explains the increase of this variable because of the acidification of the medium. The increase in $\mathrm{H}+\mathrm{Al}$ generated with the application of the byproduct in the presence of mineral fertilization was $2.2 \mathrm{mmol}_{\mathrm{c}} \mathrm{dm}^{-3}$ for each $9 \mathrm{tha}^{-1}$, while without it the increase was $1.5 \mathrm{mmol}_{\mathrm{c}} \mathrm{dm}^{-3}$ (Table 1). Therefore, as happened with $\mathrm{pH}$, the mineral fertilization more intensely 
affected the potential acidity of the soil. This was expected due to the high doses of nitrogen fertilizer, which characteristically produces soil acidification during the nitrification process (Malavolta, 2006).

For the BS attribute (Table 1), even without a significant interaction between the organic and mineral fertilization factors, there was a significant increase in the values in function of changes in the concentrations of calcium, magnesium and potassium in the soil.

The cation exchange capacity (Figure 2a) also fit the rising linear model as a function of byproduct dose, both with and without mineral fertilization. The elevation of $\mathrm{T}$ can be related to the increase in organic matter, due to the direct relation between these two attributes, since organic matter is the main factor promoting the adsorption of cations from minerals in the soil (Ciotta et al., 2003).

With mineral fertilization, the increase in $\mathrm{T}$ with rising byproduct doses was $4.0 \mathrm{mmol}_{\mathrm{c}} \mathrm{dm}^{-3}$ for each $9 \mathrm{tha}^{-1}$, but without mineral fertilization this increase was only $2.3 \mathrm{mmol}_{\mathrm{c}} \mathrm{dm}^{-3}$. Corrêa et al. (2005) reported that the application of this same type of residue during an incubation period of 90 days did not significantly affect the CEC.

The base saturation was influenced by the treatments (Figure 2b), also fitting the linear model, both with and without mineral fertilization. The values declined with increasing byproduct doses. This result is in line with those for $\mathrm{pH}$ and potential acidity, both of which have a direct relation with the base saturation of the soil. In the presence of mineral fertilization, the decrease in the base saturation was $1.3 \%$ for each $9 \mathrm{t} \mathrm{ha}^{-1}$ of byproduct, while without mineral fertilization the figure was $1.2 \%$.

The sulfur concentration in the soil (Figure 2c) increased quadratically with rising byproduct doses in the absence of mineral fertilization, but with this fertilization there was no significant effect. The likely reason is that the simple superphosphate used in the mineral fertilization contains from 100 to 120 grams of sulfur (S) per kilogram.

The rising doses of guava processing byproduct provided a quadratic increase in the boron concentration in the soil (Figure 2d). This can be explained by the mineralization of the organic matter, since it is a source of various elements, including B.

The quadratic model also provided the best fit regarding copper concentration (Figure 2e) in function of increasing byproduct doses, irrespective of mineral fertilization.

There was also an increase in the soil iron concentration with rising byproduct doses (Table 2). In the absence of mineral fertilization this increase was linear, while with fertilization the quadratic model best fit the data (Figure 2f). According to Malavolta (2006), as $\mathrm{pH}$ declines the availability of iron increases, which can explain the increase in this element's concentration, because the application of the byproduct reduced the $\mathrm{pH}$ values, enabling availability of higher quantities or Fe. The same behavior would be expected for $\mathrm{Mn}$, but no significant difference was observed in relation to the treatments. This can possibly be related to the high coefficient of variation.

Finally, in the case of zinc (Figure 2g), there was a quadratic increase with application of rising byproduct doses without application of mineral fertilization, while the increase was linear in its presence. Again according to Malavolta (2006), under acidic conditions there is greater availability of cationic micronutrients.

\section{Conclusions}

Under the experimental conditions, the attributes $\mathrm{pH}, \mathrm{OM}, \mathrm{K}, \mathrm{Mg}, \mathrm{BS}, \mathrm{T}, \mathrm{V}, \mathrm{B}, \mathrm{Fe}, \mathrm{Zn}$ and $\mathrm{S}_{-} \mathrm{SO}_{4}{ }^{2-}$ were affected by the doses of the byproduct of guava processing and by the presence or absence of mineral fertilization.

With the application of mineral fertilizer, the variables $\mathrm{OM}, \mathrm{K}, \mathrm{H}+\mathrm{Al}, \mathrm{T}, \mathrm{Fe}$ and $\mathrm{Zn}$ increased more in function or rising byproduct doses than they did without this fertilization.

These results demonstrate the potential of using guava processing residue in the cycling and supply of nutrients. 
(a)

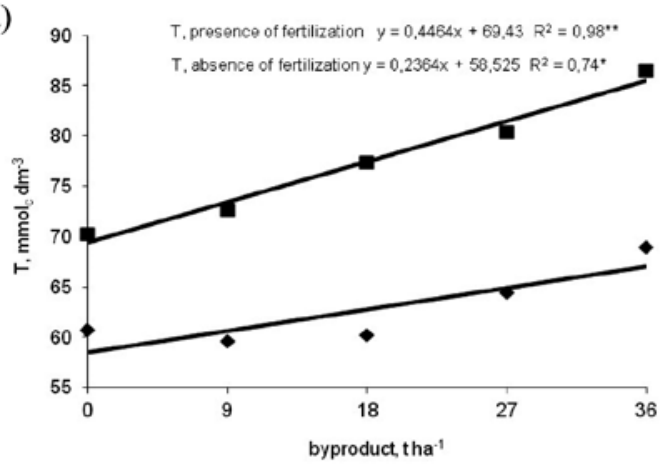

(c)

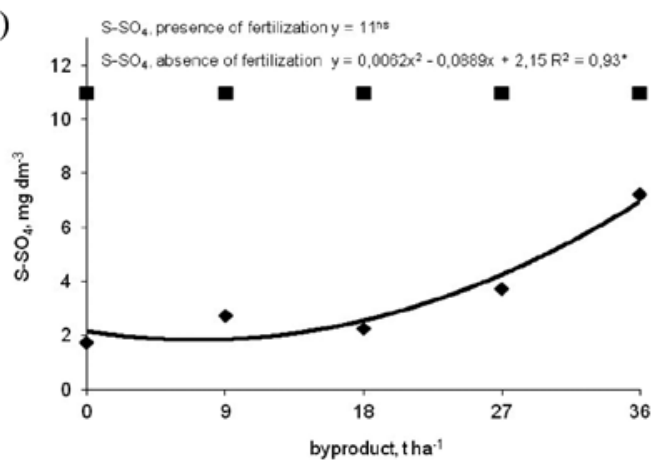

(e)

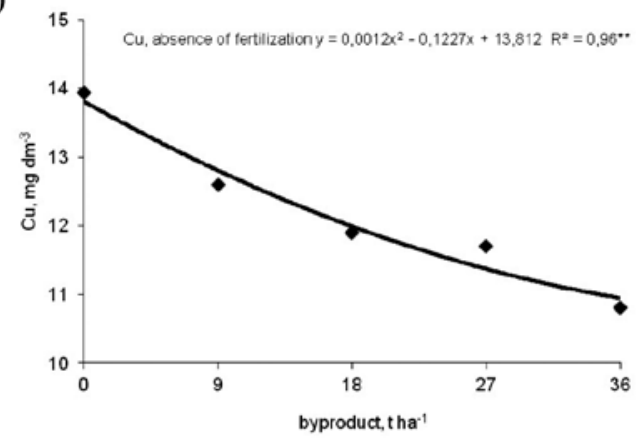

(g) Zn, presence of fertilization $y=0,0053 x+1,165 R^{2}=0,59^{* *}$

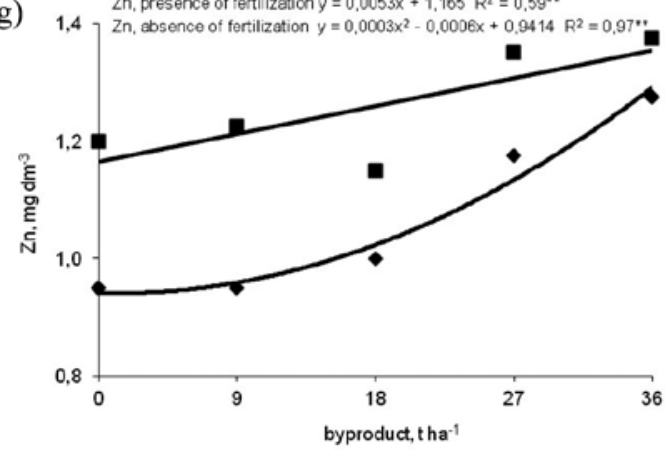

(b)

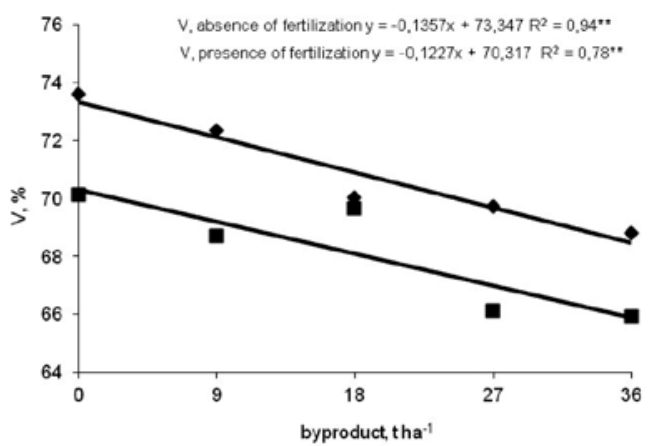

(d)

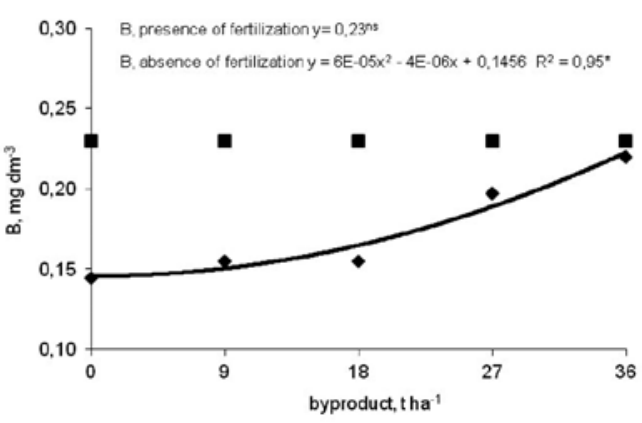

(f)

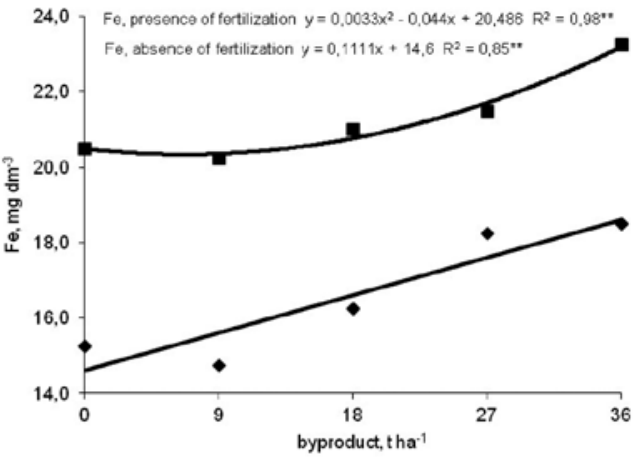

Figure 2. Effect of applying increasing doses of guava byproduct, in the absence () and presence () of mineral fertilization, on the parameters T (a); V (b); S-SO42- (c); B (d); Cu (e); Fe (f) and Zn (g).

$* \mathrm{e} * *-\mathrm{p}<0.05$ and $\mathrm{p}<0.01$ respectively. 


\section{Literature Cited}

Agrianual

2013. Anuário da agricultura brasileira. São Paulo: FNP. $480 \mathrm{p}$.

Barbosa, J.C.; Maldonado Júnior, W.

2009. Software AgroEstat-Sistema de análises estatísticas de ensaios agronômicos. Universidade Estadual Paulista, Faculdade de Ciências Agrárias e Veterinárias, Câmpus de Jaboticabal, Brazil.

Bataglia, O.C.; Furlani, A.M.C.; Teixeira, J.P.F.; Furlani, P.R.; Gallo, J.R.

1983. Métodos de análise química de plantas. Campinas: Instituto Agronômico, 48 p.

Berton, R.S.; Camargo, O.A.; Valadares, J.M.A.S.

1989. Absorção de nutrientes pelo milho em resposta à adição de lodo de esgoto a cinco solos paulistas. Revista Brasileira de Ciência do Solo, 13(1): 187-192.

Ciotta, M.N.C.; Bayer, C.; Fontoura, S.M.V.; Ernani, P.R.; Albuquerque, J.A.

2003. Matéria orgânica e aumento da capacidade de troca de cátions em solo com argila de atividade baixa sob plantio direto. Ciência Rural, 33(6): 1161-1164.

Corrêa, M.C.M.; Fernades, G.C.; Prado, R. de M.; Natale, W. 2005. Propriedades químicas do solo tratado com resíduo orgânico da indústria processadora de goiabas. Revista Brasileira Agrociência, 11(1): 241-243.

EMBRAPA-Empresa Brasileira de Pesquisa Agropecuária 2006. Centro Nacional de Pesquisa de Solos. Sistema brasileiro de classificação de solos. 2nd ed. Rio de Janeiro, $306 \mathrm{p}$.

LUPA-Levantamento censitário de unidades de produção agrícola do Estado de São Paulo 2007/2008
2010. Coordenadoria de Assistência Técnica Integral. Instituto de Economia Agrícola. Secretaria de Agricultura e Abastecimento. São Paulo: SAA/CATI/IEA, 2008. Available at: <http://www.cati.sp.gov.br/projetolupa $>$. Consulted on July $21,2010$.

Malavolta, E.

1989. ABC da adubação. Ceres, São Paulo, 5th ed., 255 p.

Malavolta, E.

2006. Manual de nutrição mineral de plantas. Piracicaba: Ceres. $631 \mathrm{p}$.

Mantovani, J.R.; Corrêa, M.C.M.; Cruz, M.C.P.; Ferreira, M.E.; Natale, W.

2004. Uso fertilizante de resíduo da indústria processadora de goiabas. Revista Brasileira de Fruticultura, 26(2): 339-342.

Natale, W.; Coutinho, E.L.M.; Boaretto, A.E.; Pereira, M.E.

1996. Goiaba: calagem e adubação. FUNEP, Jaboticabal, $22 \mathrm{p}$.

Natale, W.; Prado, R. de M.; Rozane, D.E.; Romualdo, L.M. 2007. Efeitos da calagem na fertilidade do solo e na nutrição e produtividade da goiabeira. Revista Brasileira de Ciência do Solo, 31(6): 1475-1485.

Novais, R.F.; Smyth, T.J.

1999. Fósforo em solo e planta em condições tropicais, Viçosa, $399 \mathrm{p}$.

Prado, R. de M.; Natale, W.

2005. Desenvolvimento inicial e estado nutricional do maracujazeiro em reposta à aplicação de lodo têxtil. Pesquisa Agropecuária Brasileira, 40(6): 621-626.

Raij, B. van, Andrade, J.C.; Cantarela, H.; Quaggio, J.A.

2001. Análise química para avaliação da fertilidade de solos tropicais. Campinas: Instituto Agronômico, 285 p. 